Europe PMC Funders Group

Author Manuscript

Naunyn Schmiedebergs Arch Pharmacol. Author manuscript; available in PMC 2009 May

05.

Published in final edited form as:

Naunyn Schmiedebergs Arch Pharmacol. 2007 December ; 376(4): 265-274. doi:10.1007/

s00210-007-0198-y.

\title{
Cholinergic innervation of the guinea-pig isolated vas deferens
}

\author{
Pravesh Solanki, Alina M. Cuprian-Beltechi, and Thomas C. Cunnane \\ Department of Pharmacology, University of Oxford, Mansfield Road, Oxford OX1 3QT, UK, e- \\ mail: tom.cunnane@pharm.ox.ac.uk
}

\begin{abstract}
Recently, a cholinergic neurogenic component of contraction has been characterised in the aganglionic mouse vas deferens. In this paper, a cholinergic component of contraction in the guinea-pig vas deferens is characterised pharmacologically. A residual, tetrodotoxin-sensitive (TTX, $0.3 \mu \mathrm{M}$ ), neurogenic contraction was revealed after prolonged exposure (5 h) to the adrenergic neurone blocker bretylium $(20 \mu \mathrm{M})$ or in the presence of prazosin $(100 \mathrm{nM})$ and $\alpha, \beta$ methylene ATP $(1 \mu \mathrm{M})$, a purinergic agonist which desensitizes P2X receptors. The bretyliumresistant component was potentiated by the acetylcholinesterase (AChE) inhibitor neostigmine (10 $\mu \mathrm{M})$ and inhibited by the muscarinic-receptor (mAChR) antagonist cyclopentolate $(1 \mu \mathrm{M})$. Nicotine $(30 \mu \mathrm{M})$ enhanced the bretylium-resistant component. Neostigmine increased the second component of contraction in the presence of prazosin and a, $\beta$-methylene ATP, whilst yohimbine $(1 \mu \mathrm{M})$, an $\alpha_{2}$ adrenergic receptor antagonist, enhanced both the first and second components of the electrically evoked contraction. These enhanced contractions were blocked by cyclopentolate in both cases. Nicotine enhanced the cholinergic component of contraction revealed by neostigmine but failed to have any detectable effects in the presence of cyclopentolate. Neostigmine alone increased the slow component of contraction which was reversed by cyclopentolate to control levels. The $\mathrm{M}_{3}$ receptor-antagonist 4-DAMP (10 $\mathrm{nM}$ ) markedly inhibited the cholinergic component of contraction to a level comparable with cyclopentolate. Laser microscopy has shown that neostigmine also increased the frequency of spontaneous $\mathrm{Ca}^{2+}$ transients remaining in smooth muscle cells after perfusion with prazosin and $\alpha, \beta$-methylene ATP, an effect blocked by 4-DAMP. These experimental data show that there is a functional cholinergic innervation in the guinea-pig vas deferens whose action is limited by acetylcholinesterase, blocked by cyclopentolate and mediated through M3 receptors. Moreover, by blocking the cholinesterase, the increased amount of ACh generates spontaneous $\mathrm{Ca}^{2+}$ transients in smooth muscle cells.
\end{abstract}

\section{Keywords}

Guinea-pig vas deferens; Cholinergic innervation; Neostigmine; Bretylium; Muscarinic receptor subtypes; $\mathrm{Ca}^{2+}$ transients; Confocal microscopy

\section{Introduction}

The innervation of the rodent vas deferens is unusual in that it is supplied by short intact postganglionic sympathetic neurons whose cell bodies lie within the hypogastric ganglia situated close to the prostatic end (Sjöstrand 1965; Ferry 1967; Morris and Gibbins 1992). Pharmacological and electrophysiological studies strongly suggest that ATP and noradrenaline (NA) act as the two most important co-transmitters at the sympathetic

(C) Springer-Verlag 2007

Correspondence to: Thomas C. Cunnane. 
neuroeffector junction in rodent vas deferens (Sneddon et al. 1996). Classically, the neurogenic contraction of the vas deferens is described as being biphasic, consisting of a fast 'twitch' component mediated through ATP action at P2X receptors, followed by a slow, better-maintained 'hump' component, which is mediated by NA action at a-adrenoceptors. In the guinea-pig vas deferens, acetylcholine $(\mathrm{ACh})$ has been shown to potentiate the purinergic component of sympathetic transmission (Sjöstrand 1973; Iram and Hoyle 2005). Indeed, it has been demonstrated in the same preparation that the cholinergic nerves possess an excitatory action not only directly at the smooth muscle but also at the noradrenergic terminals (Fukushi and Wakui 1986a). Furthermore, prejunctional nicotinic acetylcholine receptors (nAChRs) have been demonstrated to modulate sympathetic neurotransmitter release in guinea-pig and rat vas deferens (Starke et al. 1991; Von Kugelgen and Starke 1991; Carneiro et al. 1993; Markus et al. 1996; Zago and Markus 1999).

We have recently reported a cholinergic component of contraction in the mouse vas deferens which is limited by the action of acetylcholinesterase (AChE), enhanced by nicotine and blocked by muscarinic acetylcholine receptor (mAChR) antagonists (Cuprian et al. 2005). Nicotine acts at prejunctional nicotinic acetylcholine receptors (nAChRs) and therefore increases neurotransmitter release. Data in the literature also describe a cholinergic innervation in other species (Furness and Takashi 1972 for guinea-pig; Miranda et al. 1988; Ventura et al. 1998 for rat). Electron microscopic examinations have shown that AChE is present on the plasma membrane of about $25 \%$ of the axons, which are presumably cholinergic, in the longitudinal smooth muscle tissue of the guinea-pig vas deferens (Robinson 1969; Majcen 1984). Therefore, it seems that in addition to a dense sympathetic innervation, cholinergic and sensory nerve fibres are also present in the rodent vas deferens (Wanigasekara et al. 2003; Geppetti et al. 1988; Saito et al. 1987; Hökfelt and Ljungdahl 1972; Aberdeen et al. 1990). Indeed, there is evidence to suggest the existence of independent cholinergic and adrenergic mechanisms in the guinea-pig isolated vas deferens (Bhargava et al. 1965; Fukushi and Wakui 1986b; Bell 1967; Bentley 1966; Hata et al. 1980). To support further the idea of a cholinergic functional innervation, the guinea-pig hypogastric nerve has been shown to have both adrenergic and cholinergic fibres (Clementi et al. 1969; Bell and McLean 1967).

It was also demonstrated, both in vivo and in vitro, that calcium is spontaneously and sporadically released in packets from stores within smooth muscle cells, leading to transient increases in the internal ionized calcium concentration (Bolton 2006). Smooth muscle neuroeffector $\mathrm{Ca}^{2+}$ transients (NCTs) are generated following the action of neuronally released ATP at P2X receptors (Brain et al. 2002). Surprisingly, released NA has no detectable effects on smooth muscle $\mathrm{Ca}^{2+}$ dynamics in rodent vas deferens (unpublished data). The question arises whether the cholinergic innervation could induce $\mathrm{Ca}^{2+}$ transients in guinea-pig vas deferens smooth muscle cells.

In the present study we aim to characterise pharmacologically the neurogenic cholinergic component of contraction of the guinea-pig vas deferens longitudinal smooth muscle to determine the subtype of muscarinic acetylcholine receptor involved and whether neuronally released $\mathrm{ACh}$ generates $\mathrm{Ca}^{2+}$ transients in smooth muscle cells.

\section{Materials and methods}

Male Dunkin Hartley guinea pigs (8-12 weeks) were humanely killed, by concussion and cervical dislocation (U.K. Animal Scientific Procedures Act 1986). The vasa deferentia were excised and placed in physiological saline, gassed with $95 \% \mathrm{O}_{2} / 5 \% \mathrm{CO}_{2}$ to $\mathrm{pH} 7.4$ and maintained at $37^{\circ} \mathrm{C}$. The composition of the physiological saline was (mM): $\mathrm{NaCl} 118.8$, $\mathrm{NaHCO}_{2} 25, \mathrm{NaH}_{2} \mathrm{PO}_{4} 1.13, \mathrm{KCl}$ 4.7, $\mathrm{CaCl}_{2}$ 1.8, $\mathrm{MgCl}_{2} 1.2$ and glucose 11.1. 


\section{Contraction studies}

In all experiments, the prostatic third of each vas deferens and therefore the hypogastric ganglion located nearby were removed. The surrounding connective tissue was also dissected away. Each vas deferens was mounted in a 7-ml organ bath and connected to an isometric transducer (Letica Scientific Instruments) under an initial resting tension of 9.8 $\mathrm{mN}$ to record contractions of the longitudinal smooth muscle layer. Contraction data were digitized at a sampling rate of $10 \mathrm{~Hz}$, using a MacLab/8s data acquisition system, Chart v. 3.6.8/s software (AD Instruments) and data stored on a Macintosh computer. The maximum amplitude was the criterion used to quantify the contractions. Preparations were allowed to equilibrate for $60 \mathrm{~min}$ before controls were recorded, and tissues were washed with fresh physiological saline every 20 min throughout each experiment. Electrical field stimuli were applied through two platinum ring electrodes (diameter $2 \mathrm{~mm}$, separation $3 \mathrm{~mm}$ ) connected to a digital stimulator built in-house.

Two different experimental protocols were used. In bretylium experiments, trains of 5 and 200 stimuli were applied every $30 \mathrm{~min}(0.5 \mathrm{~ms}$ duration, $10 \mathrm{~Hz}$, supra-maximal voltage). Trains of 5, 50, 100 and 200 stimuli (using the same parameters) were delivered every 20 min in experiments in which bretylium was not used. An interval of 5 min was left between each train. Contractions evoked by these stimulation protocols were abolished by tetrodotoxin (TTX, $0.3 \mu \mathrm{M}, n=6$ ).

\section{$\mathrm{Ca}^{2+}$ imaging}

In confocal experiments, the smooth muscle cells of the vasa deferentia were loaded by exposing the isolated tissue to a 10- $\mu \mathrm{M}$ solution of Oregon Green 488 BAPTA-1 AM (dissolved in $1 \%$ DMSO, $0.2 \%$ pluronic acid) in Krebs for $2 \mathrm{~h}$ at $36^{\circ} \mathrm{C}$. The preparations were then rinsed in Krebs at $36^{\circ} \mathrm{C}$ for $30 \mathrm{~min}$ before being transferred to a $2-\mathrm{mL}$ bath, placed on the stage of Leica TCS NT laser scanning confocal microscope, and secured with parallel platinum electrodes at the prostatic end. Preparations were perfused with Krebs solution at 2 $\mathrm{ml} / \mathrm{min}$ and maintained at $37^{\circ} \mathrm{C}$. Drugs were applied by swapping the Krebs perfusing the preparation with one containing the drug at the required final bath concentration. The selection criterion for an area to focus upon was to find an area of smooth muscle cells (identified by their characteristic morphology) that were well loaded by indicator (to the eye) and responded to electrical field stimulation (i.e. generated NCTs).

The specimen was stimulated using an isolated stimulator (Digitimer DS2). The pulse width was set at $0.1 \mathrm{~ms}$, and the applied voltage was adjusted to give a reliable supra-maximal response following a single stimulus. The stimuli were electronically synchronised with the confocal microscope scans. The 488-nm wavelength of an argon-ion laser was used for excitation of fluorescence, which was filtered by a 515 -nm long-pass emission filter. When detecting $\mathrm{Ca}^{2+}$ transients, images (256×256 pixels) were captured over 128 frames $0.8 \mathrm{~s}$ apart. Colour changes in the look-up table (LUT) from orange to yellow to white to blue represent the increasing amount of $\mathrm{Ca}^{2+}$ binding to the indicator. The blue colour indicates pixel saturation and therefore these pixels were eliminated from data analysis. All experiments were carried out in the presence of prazosin $\left(100 \mathrm{nM}\right.$, a competitive $a_{1^{-}}$ adrenoceptor antagonist) and $\alpha, \beta$-MeATP $(1 \mu \mathrm{M}$, a P2X-receptor desensitising agent) to reduce responses as a result of sympathetically released NA and ATP and also to reduce any movement artefact associated with high-frequency stimulation.

\section{Image analysis}

Image analysis was performed using NIH Image 1.63 (http://rsb.info.nih.gov/nih-image/). Changes in fluorescence in smooth muscle cells $\left(\mathrm{Ca}^{2+}\right.$ transients) were measured using custom macros written by K. Brain. These macros were based upon the 'Particle Analysis' 
algorithm of NIH Image. To smooth the images and reduce erroneous counting, raw images were convolved with a Gaussian filter of half-width $1.5 \mathrm{~mm}$. The ratios of the fluorescence intensity between consecutive images were calculated on a pixel-by-pixel basis. The Particle Analysis algorithm was used to detect changes in the ratio of fluorescence intensities of $25 \%$ over an area of at least $2.5 \mathrm{~mm}^{2}$. A threshold was set, based on the background signal of the image series, below which the algorithm did not search for events. Each event was manually checked to confirm that there were no focal plane shifts or movement within the focal plane that may have caused over-counting; such aberrant events were excluded from the analysis. In experiments in which there was considerable movement, all events were manually counted by eye.

\section{Drugs}

Stock solutions of TTX, $a, \beta$-methyleneATP ( $a, \beta$-MeATP) lithium salt, atropine sulphate, cyclopentolate hydrochloride, neostigmine bromide, bretylium tosylate, yohimbine hydrochloride, nicotine hydrogen tartrate and pirenzepine dihydrochoride were prepared in distilled water. Prazosin hydrochloride, AF-DX 116, 4-DAMP and PD 102807 were dissolved in dimethyl sulfoxide (DMSO). Solutions were aliquoted and stored at $-20^{\circ} \mathrm{C}$, ensuring that the drugs only passed through one freeze-thaw cycle. The drugs were serially diluted in Krebs to the required final concentration on the day of use. Vehicle controls had no effects. All compounds were obtained from Sigma (Dorset, England) except the muscarinic antagonists AF-DX 116, 4-DAMP, PD 102807 and pirenzepine dihydrochoride, which were obtained from Tocris (Bristol, UK).

\section{Analysis}

Data are expressed as the mean \pm SEM, $n$ representing the number of vasa deferentia used in each experiment. Statistical significance was determined using a paired Student's $t$-test. In the figures, an asterisk represents $P<0.05$.

\section{Results}

\section{Effects of bretylium on neurogenic contractions of the guinea-pig vas deferens}

The guinea-pig vas deferens responds with a biphasic 'twitch' and 'hump' contraction to long trains of nerve stimuli. Preparations were stimulated every 30 min with trains of 200 stimuli at $10 \mathrm{~Hz}$ (pulse width $0.5 \mathrm{~ms}$ ). Neurogenic contractions were recorded before, during and after prolonged (up to $5 \mathrm{~h}$ ) exposure to the adrenergic neurone blocker bretylium ( 20 $\mu \mathrm{M})$. Bretylium greatly reduced both the purinergic and noradrenergic components of electrically evoked responses. Continuous exposure (approximately $2-3 \mathrm{~h}$ ) to bretylium revealed a residual hump-like contraction (at 200 stimuli), which increased in amplitude with time, reaching a maximum after about $5 \mathrm{~h}$ (see Jackson and Cunnane 2002) (Fig. 1, $n=12, P<0.05)$. The residual evoked contraction was abolished by TTX $(300 \mathrm{nM})$.

\section{Effects of neostigmine and cyclopentolate on the bretylium-resistant component of contraction}

Neostigmine $(10 \mu \mathrm{M})$ increased the amplitude of the bretylium-resistant contraction by $114 \pm 38 \%$ (Fig. 1, $n=8, P<0.05$ ), and the subsequent addition of cyclopentolate $(1 \mu \mathrm{M}, n=8$, $P<0.05$ ) greatly reduced the contraction by $98 \pm 5 \%$. Sometimes a residual contraction was detected. The remaining contraction was TTX sensitive and abolished by capsaicine, but no further studies were conducted to analyse it in more detail. 


\section{Effects of nicotine on the bretylium-resistant component of contraction}

Nicotine $(30 \mu \mathrm{M})$ increased the amplitude of the bretylium-resistant contraction by $55 \pm 16 \%$ (Fig. 2, $n=8, P<0.05$ ), the increase being readily repeatable after a 1-h wash, without any significant change in the magnitude of potentiation. In the presence of cyclopentolate, nicotine failed to elicit a change in the amplitude of the bretylium-resistant component ( $n=8$, $P>0.05)$.

\section{Effects of neostigmine and cyclopentolate in the presence of prazosin and $\alpha, \beta-M e A T P$}

Trains of 50, 100 and 200 stimuli were delivered at $10 \mathrm{~Hz}$ to evoke classical biphasic contractions. Bath application of prazosin $(100 \mathrm{nM})$ and $a, \beta$-MeATP $(1 \mu \mathrm{M})$ inhibited the noradrenergic response of the guinea-pig vas deferens, but a small residual component of contraction was still detected after approximately $45 \mathrm{~min}$ (Fig. 3, $n=14, P<0.05$ ).

Neostigmine $(10 \mu \mathrm{M})$ increased the amplitude of this component at 50, 100 and 200 stimuli by $323 \pm 106,354 \pm 39$ and $419 \pm 101 \%$ respectively (Fig. $3, n=14, P<0.05$ ). This potentiation of the neurogenic cholinergic contraction by neostigmine was abolished by the subsequent addition of cyclopentolate $(1 \mu \mathrm{M})$.

\section{Effects of neostigmine}

Neostigmine $(10 \mu \mathrm{M})$ alone increased the hump component of the biphasic contraction by $30 \pm 9,41 \pm 7$ and $56 \pm 7 \%$ at 50,100 and 200 stimuli respectively (Fig. $4, n=6, P<0.05$ ). The effects of neostigmine were pronounced during longer trains of stimuli. This action of neostigmine was reversed by cyclopentolate $(1 \mu \mathrm{M})$. However, it is noteworthy that cyclopentolate alone did not significantly affect the biphasic contraction in control experiments $(n=8, P>0.05)$.

\section{Effects of ACh}

Bath application of ACh $(10 \mu \mathrm{M})$ elicited a contraction in the guinea-pig vas deferens $(17.23 \pm 4.09 \mathrm{mN}, n=6)$. In the presence of cyclopentolate $(10 \mu \mathrm{M})$, bath application of ACh had no detectable effect $(0.06 \pm 0.03, n=6, P<0.05)$.

\section{Effects of yohimbine in the presence of prazosin and $\alpha, \beta$-methylene ATP}

Yohimbine enhanced the biphasic contraction of the guinea-pig vas deferens evoked by trains of 50, 100 and 200 stimuli in the presence of prazosin $(100 \mathrm{nM})$ and $\alpha, \beta$-methylene ATP $(1 \mu \mathrm{M})$. The yohimbine-enhanced contractions were abolished by cyclopentolate (Fig. $5, n=8, P<0.05)$.

\section{Effects of selective mAChR antagonists}

Following postjunctional blockade of sympathetic transmission with prazosin $(100 \mathrm{nM})$ and a, $\beta$-MeATP $(1 \mu \mathrm{M})$ and potentiation of the cholinergic contraction with neostigmine, various subtype-specific $\mathrm{mAChR}$ antagonists were investigated at the concentrations found in the literature to block the muscarinic receptors. The M1-receptor antagonist, pirenzepine $(0.3 \mu \mathrm{M}), \mathrm{M} 2$-antagonist AFDX116 $(5 \mu \mathrm{M})$ and the M4-antagonist PD102807 $(10 \mu \mathrm{M})$ had no significant effect on the amplitude of the cholinergic contraction (Fig. 6, $n=8, P>0.05$ ). However, the M3-receptor antagonist 4-DAMP $(10 \mathrm{nM})$ abolished the neostigmine-induced potentiation (Fig. $6, n=8, P<0.05$ ).

\section{Effects of neostigmine on spontaneous $\mathrm{Ca}^{2+}$ transients in smooth muscle cells}

In the mouse vas deferens, Brain and colleagues have described a high-resolution method to measure neurotransmitter release from individual varicosities on the same nerve terminal branch on an impulse-to-impulse basis. Nerve-evoked neuroeffector focal $\mathrm{Ca}^{2+}$ transients 
(NCTs) were observed in smooth muscle cells intermittently. Spontaneous events (sNCTs) with comparable size, amplitude and pharmacological sensitivity were also observed, reflecting spontaneous neurotransmitter release.

In guinea-pig vas deferens in confocal microscopy experiments, the number of NCTs and sNCTs were markedly reduced by the application of prazosin $(100 \mathrm{nM})$ and $\alpha, \beta-M e A T P(1$ $\mu \mathrm{M})$. The frequency of the residual spontaneous $\mathrm{Ca}^{2+}$ transients ( 0 pulse $44.75 \pm 3.15,1$ pulse $52.5 \pm 3.5,50$ pulses at $10 \mathrm{~Hz} 44.37 \pm 2.5, n=94$ cells) was increased by neostigmine perfusion (Fig. 7, 0 pulse $223.25 \pm 18.17,1$ pulse $215.9 \pm 15.25,50$ pulses at $10 \mathrm{~Hz}$ $225.00 \pm 14.00, n=94$ cells, $P<0.05)$. In the absence of neostigmine, spontaneous $\mathrm{Ca}^{2+}$ events of low frequency were still detected, but the cholinesterase inhibitor was used to facilitate the study of these residual transients.

\section{Effects of 4-DAMP on neostigmine-induced $\mathrm{Ca}^{2+}$ transients in smooth muscle cells}

Following application of M3-receptor antagonist 4-DAMP (10 nM), the neostigmineinduced potentiation of spontaneous $\mathrm{Ca}^{2+}$ transients in guinea-pig vas deferens was markedly reduced (Fig. 7, 0 pulse $38.5 \pm 2.4,1$ pulse $89 \pm 4.5,50$ pulses at $10 \mathrm{~Hz} 47.25 \pm 5$, $n=94$ cells, $P<0.05)$.

\section{Discussion}

This study reminds us that there is a significant cholinergic innervation of the guinea-pig vas deferens. Contraction of the longitudinal muscle layer of the guinea-pig vas deferens, in response to long trains of stimuli, is thought to be solely mediated by ATP and NA released from sympathetic nerves. Similar to the work in mouse vas deferens, a TTX-sensitive, residual component of evoked contraction was evident after prejunctional blockade of sympathetic transmission by bretylium. The residual component developed after the classical purinergic 'twitch' and noradrenergic 'hump' were abolished, within $2 \mathrm{~h}$ of bretylium application, and increased in amplitude with time. Prazosin and $a, \beta$-MeATP had no effect on the amplitude of the residual component of contraction, whereas the muscarinic-receptor antagonist cyclopentolate abolished it. Bretylium reduced NA and ATP release, decreasing the contraction amplitude. However, as the concentration of released NA fell, the prejunctional inhibitory action of NA on cholinergic nerves decreased, increasing $\mathrm{ACh}$ release and generating a sizeable muscarinic contraction. Thus, in the vas deferens, the sympathetic nerves appear to inhibit the prejunctional release of ACh from cholinergic nerves in a manner analogous to that found in the gastrointestinal tract. Interestingly, although the effects of nerve-released NA on contraction were abolished rapidly, within $1 \mathrm{~h}$ of bretylium exposure, it took a further $2 \mathrm{~h}$ for the residual cholinergic component to develop fully. One possible explanation for this disparity is that the concentration of NA required to inhibit $\mathrm{ACh}$ release is much lower than that required to elicit contraction, and so, it takes much longer for NA levels to fall to a level required to overcome the inhibition of ACh release.

To support further the idea that NA acts prejunctionally to inhibit ACh release from cholinergic nerves, yohimbine, in the presence of prazosin and $a, \beta$-MeATP, enhanced the amplitude of both components of contraction, an effect abolished by cyclopentolate. In the presence of prazosin only, the postjunctional action of NA is blocked, reducing the contraction amplitude. When yohimbine was added to the bath, NA action at the $a_{2-}$ adrenoreceptor on cholinergic nerve terminals was also blocked, allowing an increase in $\mathrm{ACh}$ release and the generation of a large-amplitude, cyclopentolate-sensitive contraction.

Neostigmine is an anticholinesterase that inhibits the breakdown of ACh, allowing the actions and effects of ACh to be amplified. Neostigmine increased the amplitude of the 
hump component of contraction without significantly affecting the twitch. This potentiating effect of neostigmine was abolished by cyclopentolate. It may be argued that there is some crosstalk between cholinergic and sympathetic nerves, and the effects of neostigmine and increased ACh levels may potentiate contraction through the prejunctional potentiation of sympathetic neurotransmitter release. Iram and Hoyle (2005) have demonstrated that low concentrations of muscarinic agonists can potentiate the effects of sympathetic transmission through an M3 muscarinic mechanism. However, in the presence of prazosin and $\alpha, \beta-$ MeATP, neostigmine greatly potentiated the hump component of contraction, with little effect on the twitch, in a cyclopentolate-sensitive manner. The fact that neostigmine increased contraction suggests that $\mathrm{ACh}$ is normally released following nerve stimulation and acts postjunctionally to elicit contraction by action at postjunctional M3 mAChRs.

It is possible that $\mathrm{ACh}$ does not generate contraction directly but potentiates the purinergic contraction due to incomplete block by a, $\beta$-MeATP (Iram and Hoyle 2005). Nevertheless, bath-applied ACh elicited a cyclopentolate-sensitive contraction. It cannot be ruled out that the concentration of ACh revealed through the action of neostigmine may be insufficient to generate contraction directly but sufficient to potentiate the ATP response, so that only the hump component of contraction is amplified and the fast purinergic twitch component is unaffected.

The question remains why yohimbine enhanced both the twitch- and hump-like components of contraction whereas neostigmine only potentiated the hump. One explanation is that cholinergic nerves release both NA and ATP and the twitch represents ATP action at purinergic receptors and the hump the action of $\mathrm{ACh}$ at muscarinic receptors. In the case of neostigmine only, the actions of released ACh are amplified, which generates the hump, and the level of released ATP remains the same and is blocked by a, $\beta$-MeATP. When yohimbine is added, the 'effective' concentration of ACh and ATP released from cholinergic nerves is increased, which manifests itself as an increase in both components of contraction. It cannot be ruled out that the block of P2X receptors by a, $\beta$-MeATP is incomplete, and thus the increased levels of ATP released from cholinergic nerves can still generate the twitch contraction. The observation that both components of the yohimbine-induced potentiation are abolished by cyclopentolate suggests that either both components are generated by ACh action at muscarinic receptors or more likely that ACh acts cooperatively with ATP to generate the twitch-like contraction. In support of the latter assertion, Iram and Hoyle (2005) have demonstrated that in the guinea-pig vas deferens, activation of postjunctional M3 receptors at a level insufficient to generate contraction directly nevertheless potentiates the effects of ATP.

Thus it has been demonstrated that the bretylium-resistant component abolished by cyclopentolate and potentiated by neostigmine and yohimbine provides unequivocal evidence to support the cholinergic basis of the residual contraction, mediated through mAChRs. Moreover, it appears that physiologically cholinergic nerves are inhibited by sympathetic nerves, because cyclopentolate alone does not affect the control neurogenic contraction. Only by blocking cholinesterase does the action of ACh become sufficient to increase significantly the electrically evoked contraction, when the release of neurotransmitter from sympathetic nerves is not blocked. The need for long trains of stimuli may be due to the fact that cholinergic nerves represent only 25\% (Robinson 1969) of the innervation of the vas deferens compared to sympathetic nerves, so prolonged stimulation is required in order to be able to influence the neurogenic contraction. Occasionally there is still a residual contraction detectable after applying prazosin, $\alpha, \beta$-MeATP, neostigmine and cyclopentolate which is TTX sensitive and could be abolished by capsaicine (unpublished data). 
In mouse vas deferens, contraction and confocal studies have shown that nicotine increases the amplitude of the bretylium-resistant contraction (Cuprian et al. 2005) and spontaneous $\mathrm{Ca}^{2+}$ transients in all varicosities, located on either bretylium-sensitive or bretylium-resistant nerve terminals (Brain et al. 2001; Jackson et al. 2001; Jackson and Cunnane 2002). These nerve terminals were considered to be preterminal sympathetic fibres, sensory nerves or cholinergic nerves.

In guinea-pig vas deferens, the potentiation of the bretylium-resistant and neostigmineenhanced contractions by nicotine suggests that facilitatory nicotinic receptors are present on cholinergic nerve terminals. It may be argued that the nicotine-potentiated contraction is a result of nicotine action on sympathetic nerve terminals resulting in the release of NA and ATP. However, the fact that nicotine failed to elicit any effect in the presence of cyclopentolate supports the cholinergic origin of the nerve terminals producing the residual contraction.

In rodent vas deferens, two subtypes of mAChRs have been described (Silva et al. 1988): postjunctional $\mathrm{mAChRs} \mathrm{M3}$, involved in the potentiation of the neurogenic contraction (Matsuno and Mita 1992) and prejunctional inhibitory mAChR M1 (Miranda et al. 1995, 1994, 1987; Miranda and Wolstenholme 1985). In addition, facilitatory nicotinic receptors (Todorov et al. 1991) are present on sympathetic nerve terminals. Moreover, using KO mice, it has been shown that the inhibitory effects of cholinergic stimulation on NA release involve M2, M3 and M4 mAChRs (Trendelenburg et al. 2003).

In the present study, the neostigmine-potentiated cholinergic response was significantly reduced by the M3 muscarinic-receptor antagonist 4-DAMP but unaffected by pirenzepine, AFDX116 and PD102807, the $\mathrm{M}_{1^{-}}, \mathrm{M}_{2^{-}}$, and $\mathrm{M}_{4}$-receptor antagonists respectively. This result is consistent with the findings of Miranda et al. (1995), who demonstrated that the postjunctional responses to muscarinic agonists were mediated by a receptor pharmacologically similar to the M3 subtype in the rat vas deferens.

Brain et al. (2002) have previously shown that $\mathrm{Ca}^{2+}$ transients evoked by nerve stimulation, known as NCTs, occur in distinct clusters, adjacent to identified varicosities and generated by the discrete release of ATP acting at P2X receptors. On the other hand, neuronally released NA did not detectably alter $\mathrm{Ca}^{2+}$ dynamics. In order to isolate any cholinergic events and to inhibit possible $\mathrm{Ca}^{2+}$ transients mediated by sympathetically released ATP, experiments were carried out in the presence of prazosin and $\alpha, \beta$-MeATP. Following inhibition of $\mathrm{AChE}$ with neostigmine, spontaneous $\mathrm{Ca}^{2+}$ transients occurred in the absence of electrical stimulation. This interesting and surprising observation is consistent with a basal release, under resting conditions, of $\mathrm{ACh}$, whose effects in generating $\mathrm{Ca}^{2+}$ events in smooth muscle are limited by the action of cholinesterase. Since these events were abolished by 4-DAMP, it appeared that they were generated through the activation of muscarinic M3 receptors. The origin of $\mathrm{ACh}$ producing these $\mathrm{Ca}^{2+}$ transients could be either neuronal or spontaneous neurotransmitter leakage through choline transporters inserted into the membrane during exocytosis. It is noteworthy that, following nerve stimulation, $\mathrm{Ca}^{2+}$ waves were evoked and travelled at an average speed of $15.6 \mu \mathrm{m} / \mathrm{s}$.

The functional significance of the cholinergic innervation remains to be determined.

Investigations are ongoing to determine the precise anatomical locations of the nAChRs and mAChRs that mediate cholinergic neurotransmission.

In summary, it has been demonstrated that there is a functional cholinergic innervation of the guinea-pig vas deferens that evokes calcium transients and contraction through action of 
released ACh at M3 mAChRs. The action of ACh is limited by cholinesterase, and ACh release is modulated by prejunctional nAChRs and sympathetic nerves.

\section{Acknowledgments}

We would like to thank The Wellcome Trust for financial support.

\section{Abbreviations}

$\begin{array}{ll}\text { ATP } & \text { Adenosine triphosphate } \\ \mathbf{a}, \beta-M e A T P & a, \beta \text {-Methylene ATP } \\ \text { mAchR } & \text { Muscarinic receptor } \\ \text { nAchR } & \text { Nicotinic receptor } \\ \text { TTX } & \text { Tetrodotoxin }\end{array}$

\section{References}

Aberdeen J, Corr L, Milner P, Lincoln J, Burnstock G. Marked increases in calcitonin gene-related peptide-containing nerves in the developing rat following long-term sympathectomy with guanethidine. Neuroscience. 1990; 35:175-184. [PubMed: 2113638]

Bell C. An electrophysiological study of the effects of atropine and physostigmine on transmission to the guinea-pig vas deferens. J Physiol. 1967; 189:31-42. [PubMed: 16992244]

Bell C, McLean JR. Localization of norepinephrine and acetylcholinesterase in separate neurons supplying the guinea-pig vas deferens. J Pharmacol Exp Ther. 1967; 157(1):69-73. [PubMed: 6029493]

Bentley GA. The effect of local anaesthetic and anti-adrenaline drugs on the response of sympathetically innervated smooth muscle preparations to electrical stimulation at different frequencies. Br J Pharmac Chemother. 1966; 27:64-80.

Bhargava KP, Kar K, Parmar SS. Independent cholinergic and adrenergic mechanisms in the guineapig isolated nerve vas deferens preparation. B J Pharmcol. 1965; 24:641-650.

Bolton TB. Calcium events in smooth muscles and their interstitial cells; physiological roles of sparks. J Physiol. 2006; 570(1):5-11. [PubMed: 16195319]

Brain KL, Trout SJ, Jackson VM, Dass N, Cunnane TC. Nicotine induces calcium spikes in single nerve terminal varicosities: a role for intracellular calcium stores. Neuroscience. 2001; 106(2):395403. [PubMed: 11566509]

Brain KL, Jackson VM, Trout SJ, Cunnane TC. Intermittent ATP release from nerve terminals elicits focal smooth muscle $\mathrm{Ca}^{2+}$ transients in mouse vas deferens. J Physiol. 2002; 541(3):849-862. [PubMed: 12068045]

Carneiro RC, Markus RP, Dubocovich ML. Presynaptic modulation by melatonin of the nicotinicinduced calcium-dependent release of norepinephrine from the rat vas deferens. Biol Signals. 1993; 2(4):199-206. [PubMed: 8205163]

Clementi F, Naimzada KM, Montegazza P. Study of the nerve endings in the vas deferens and seminal vesicles of the guinea-pig. Int J Neuropharmacol. 1969; 8:399-403. [PubMed: 5344485]

Cuprian AM, Solanki P, Jackson MV, Cunnane TC. Cholinergic innervation of the mouse isolated vas deferens. Br J Pharmacol. 2005; 146:927-934. [PubMed: 16170331]

Ferry CB. The innervation of the vas deferens of the guinea-pig. J Physiol Lond. 1967; 192:463-478. [PubMed: 6050158]

Fukushi Y, Wakui M. Possible interactions of cholinergic nerves with two different (pre and post) sites of the neuromuscular junction in guinea-pig vas deferens. J Auton Pharmac. 1986a; 5:291-297.

Fukushi Y, Wakui M. Pharmacological studies on the role of cholinergic nerves in the neuromuscular transmission in the circular smooth muscle of the guinea-pig vas deferens. J Auton Pharmac. 1986b; 5:299-304. 
Furness JB, Iwayama T. The arrangement and identification of axons innervating the vas deferens of the guinea-pig. J Anat. 1972; 113(2):179-196. [PubMed: 4664233]

Geppetti P, Frilli S, Renzi D, Santicioli P, Maggi CA, Theodorsson E, Franciullacci M. Distribution of calcitonin generelated peptide-like immunoreactivity in various rat tissues: correlation with substance P and other tachykinins and sensitivity to capsaicin. Regul Pept. 1988; 23:289-298. [PubMed: 2467330]

Hata F, Kunio T, Yoshio M, Ron-Tsan L, Hajime I, Hiroshi Y. Specific changes in the cholinergic system in guinea-pig vas deferens after denervation. J Pharmacol Exp Ther. 1980; 215(3):716722. [PubMed: 6255138]

Hökfelt TG, Ljungdahl AS. Histochemical determination of neurotransmitter distribution. Res Publ Assoc Res Nerv Ment Dis. 1972; 50:1-24. [PubMed: 4404674]

Iram $\mathrm{S}$, Hoyle $\mathrm{C}$. Potentiation of sympathetic neuromuscular transmission mediated by muscarinic receptors in guinea-pig isolated vas deferens. Naunyn-Schmiedeberg's Arch Pharmacol. 2005; 371:212-220. [PubMed: 15900515]

Jackson VM, Cunnane TC. Bretylium or 6-OHDA-resistant, action potential-evoked $\mathrm{Ca}^{2+}$ transients in varicosities of the mouse vas deferens. Br J Pharmacol. 2002; 135:1845-1850. [PubMed: 11959786]

Jackson VM, Trout SJ, Brain KL, Cunnane TC. Characterisation of action potential-evoked calcium transients in postganglionic sympathetic axon bundles. J Physiol. 2001; 537:3-16. [PubMed: 11711556]

Majcen Z. Cholinesterases and choline acetyltransferase in the ductus deferens of the guinea-pig. Histochemistry. 1984; 81(2):195-199. [PubMed: 6490405]

Markus RP, Zago WM, Carneiro RC. Melatonin modulation of presynaptic nicotinic acetylcholine receptors in the rat vas deferens. J Pharmacol Exp Ther. 1996; 279(1):18-22. [PubMed: 8858970]

Matsuno K, Mita S. Involvement of the muscarinic receptors in the postsynaptic potentiation of neurogenic twitch contraction in the mouse vas deferens. Lif Sci. 1992; 50(11):799-806.

Miranda HF, Wolstenholme WW. Presynaptic regulation of Ach of the NE mediated responses in the rat vas deferens. J Recept Res. 1985; 5(4):231-243. [PubMed: 2997445]

Miranda HF, Wolstenholme WW, Moreu GM, Santiago PA. Ontogenesis of autonomic receptors and AchE activity in the rat vas deferens. Gen Pharmacol. 1987; 18(4):425-429. [PubMed: 3609698]

Miranda HF, Wolstenholme WW, Moreu GM, Santiago PA. Effects of haloperidol on neurotransmitter activity in the rat vas deferens. Gen Pharmacol. 1988; 19(1):123-127. [PubMed: 2894332]

Miranda HF, Duran E, Bustamante D, Paeile C, Pinardi G. Pre- and postjunctional muscarinic receptors subtyes in the vas deferens of rat. Gen Pharmacol. 1994; 25(8):1643-1647. [PubMed: 7721040]

Miranda HF, Duran E, Fernandez E, Pinardi G. Muscarinic receptors subtypes in the bisected vas deferens of the rat. Gen Pharmacol. 1995; 26(2):387-391. [PubMed: 7590092]

Morris, JL.; Gibbins, IL. Co-transmission and neuromodulation, in autonomic neuroeffector mechanisms. Harwood Academic; Philadelphia: 1992. p. 33-121.

Robinson PM. A cholinergic component in the innervation of the longitudinal smooth muscle of the guinea-pig vas deferens - the fine structural localization of acetylcholinesterase. J Cell Biol. 1969; 41:462-476. [PubMed: 5783868]

Saito A, Tomobe Y, Goto K. Effect of capsaicin on smooth muscles of rat vas deferens: involvement of calcitonin gene-related peptide? J Pharmacol Exp Ther. 1987; 242:665-672.

Silva WI, Wolstenholme WW, Miranda HI. Pre- and postsynaptic muscarinic receptors of the rat vas deferens: an update. P R Health Sci J. 1988; 7(2):105-110. [PubMed: 3186917]

Sjöstrand NO. The adrenergic innervation of the vas deferens and the accessory male genital organs. Acta Physiol Scand, Suppl. 1965; 257:1-82.

Sjöstrand NO. Effects of acetylcholine and some other smooth stimulants on the electrical and mechanical responses of the guinea-pig vas deferens to nerve stimulation. Acta Physiol Scand. 1973; 89:1-9. [PubMed: 4357472]

Sneddon P, McLaren GJ, Kennedy C. Purinergic co-transmission: sympathetic nerves. Sem Neurosci. 1996; 8:201-205. 
Starke K, Bultmann R, Bulloch JM, Von Kulgelgen I. Noradrenaline-ATP corelease and cotransmission following activation of nicotine receptors at postganglionic sympathetic axons. J Neural Transm Suppl. 1991; 34:93-98. [PubMed: 1667873]

Todorov L, Windisch K, Shersen H, Lajitha A, Papasova M, Vizi ES. Prejunctional nicotinic receptors involved in facilitation of stimulation-evoked noradrenaline release from the vas deferens of the guinea-pig. Br J Pharmacol. 1991; 102(1):186-190. [PubMed: 2043921]

Trendelenburg AU, Gomeza J, Klebroff W, Zhou H, Wess J. Heterogeneity of presynaptic muscarinic receptors mediating inhibition of sympathetic transmitter release: a study with $\mathrm{M}_{2-}$ and $\mathrm{M}_{4-}$ receptor-deficient mice. Br J Pharmacol. 2003; 138:469-480. [PubMed: 12569072]

Ventura S, Bavetta S, Milner P, Ralevic V, Burnstock G. Nitric oxide synthase is co-localized with vasoactive intestinal poly-peptide in postganglionic parasympathetic nerves innervating the rat vas deferens. Neuroscience. 1998; 83:607-616. [PubMed: 9460767]

Von Kugelgen I, Starke K. Release of noradrenaline and ATP by electrical stimulation and nicotine in guinea-pig vas deferens. Naunyn Schmiedebergs Arch Pharmacol. 1991; 344(4):419-429. [PubMed: 1662775]

Wanigasekara Y, Kepper ME, Keast JR. Immunohistochemical characterisation of pelvic autonomic ganglia in male mice. Cell Tiss Res. 2003; 311(2):175-185.

Zago WM, Markus RP. Melatonin modulation of presynaptic nicotinic acetylcholine receptors located on short noradrenergic neurons of the rat vas deferens: a pharmacological characterization. Braz $\mathrm{J}$ Med Biol Res. 1999; 32(8):999-1006. [PubMed: 10454762] 




Fig. 1.

Effects of neostigmine and cyclopentolate on the bretylium-resistant contraction. Typical traces showing electrically evoked contractions produced by trains of 200 stimuli $(10 \mathrm{~Hz})$. Bretylium $(20 \mu \mathrm{M})$ reduced the neurogenic contraction and revealed a residual component of contraction that was increased by neostigmine and abolished by subsequent addition of cyclopentolate $(1 \mu \mathrm{M})$ 




Fig. 2.

Histogram showing the effect of nicotine on residual contraction. Continuous exposure (approximately $2-3$ hours) to bretylium revealed a residual hump-like contraction (at 200 stimuli), which increased in amplitude with time, reaching a maximum after about 5 hours. Nicotine $(30 \mathrm{mM})$ increased the amplitude of the residual neurogenic contraction 


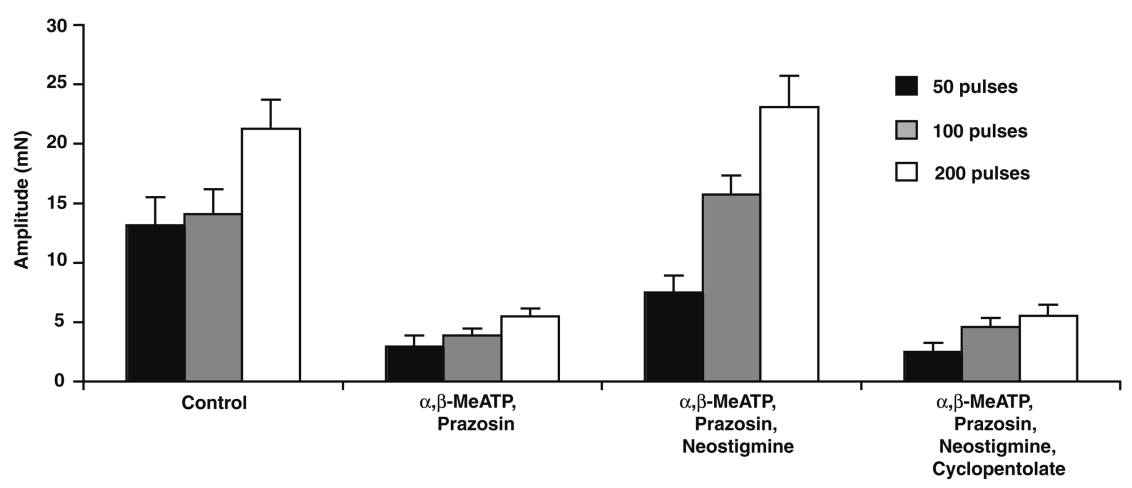

Fig. 3.

Effect of neostigmine on electrically evoked contractions in the presence of $\alpha, \beta-$ MeATP and prazosin. Histogram showing the amplitude of contractions evoked by trains of 5, 50, 100 and 200 stimuli $(10 \mathrm{~Hz})$. The amplitude of contraction was greatly reduced following the addition of prazosin $(100 \mathrm{nM})$ and $a, \beta$-MeATP $(1 \mu \mathrm{M})$. Neostigmine $(1 \mu \mathrm{M})$ increased this residual contraction; the effect was reversed by cyclopentolate $(1 \mu \mathrm{M})$ 


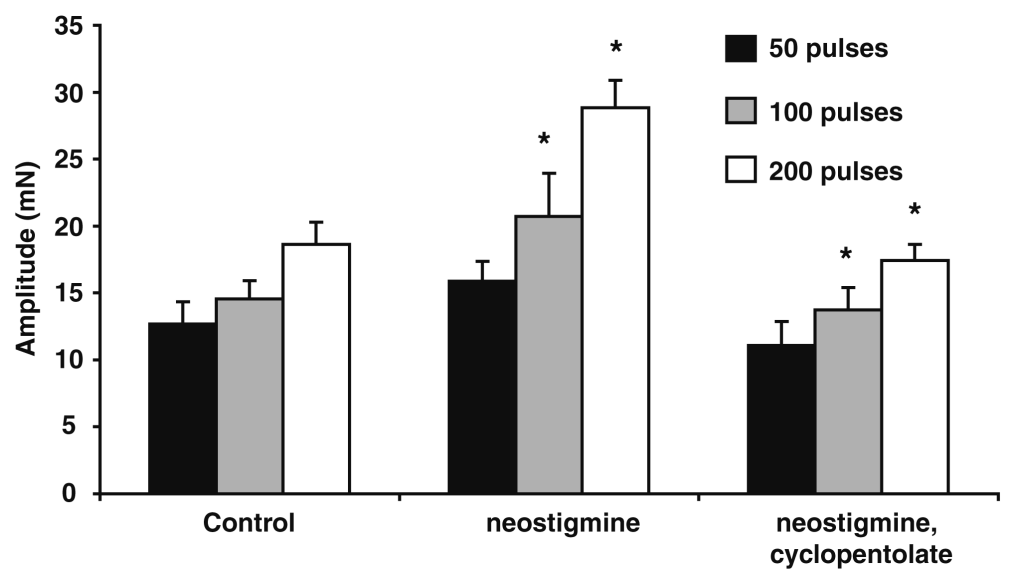

Fig. 4.

Effect of neostigmine on the electrically evoked contraction. Histogram showing the amplitude of contractions evoked by trains of 5, 50, 100 and 200 stimuli $(10 \mathrm{~Hz})$. The amplitude of contraction increased following the addition of neostigmine $(1 \mu \mathrm{M})$, an effect that was reversed by cyclopentolate $(1 \mu \mathrm{M})$ 


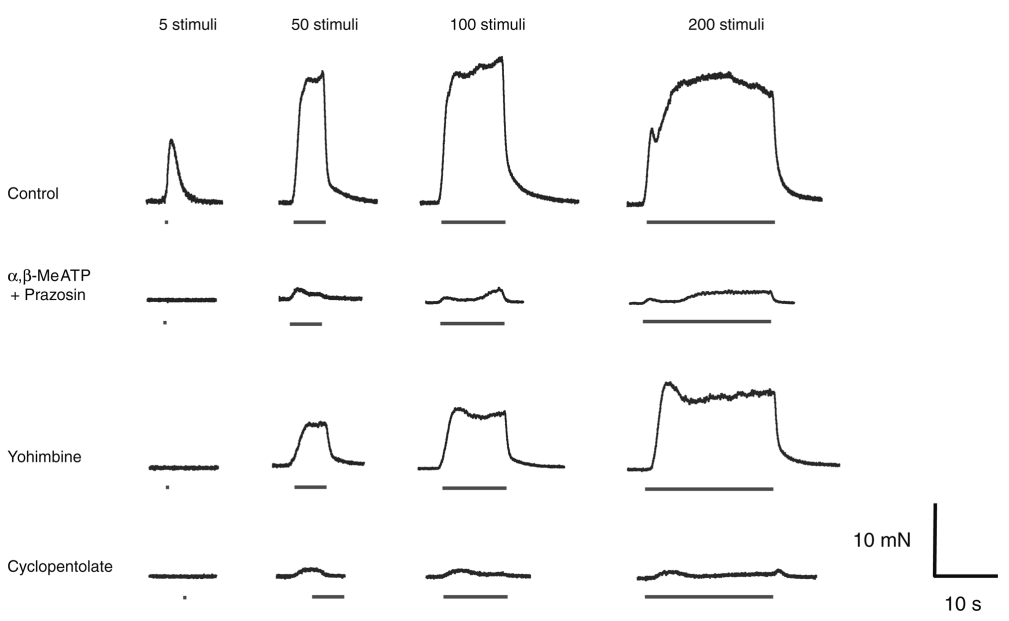

Fig. 5.

Effect of yohimbine on the electrically evoked contraction in the presence of $a, \beta$-MeATP and prazosin. Typical traces showing contractions evoked by trains of 5, 50, 100 and 200 stimuli $(10 \mathrm{~Hz})$. Following blockade of $\mathrm{a}_{1}$-adrenoceptors and $\mathrm{P} 2 \mathrm{X}$ receptors with prazosin $(100 \mathrm{nM})$ and $a, \beta$-MeATP $(1 \mu \mathrm{M})$ respectively, yohimbine $(1 \mu \mathrm{M})$ increased both components of contraction evoked by trains of 50 stimuli or more, and this effect was reversed by cycoplentolate $(1 \mu \mathrm{M})$ 



Fig. 6.

Effect of specific muscarinic-receptor antagonists on the cholinergic electrically evoked contraction. Histogram showing the amplitude of contractions evoked by trains of 5, 50, 100 and 200 stimuli $(10 \mathrm{~Hz})$. The amplitude of contraction was greatly reduced following the addition of prazosin and $a, \beta$-MeATP. Neostigmine $(1 \mu \mathrm{M})$ increased the residual contraction, an effect that was reversed by the M3 muscarinic-receptor antagonist 4-DAMP $(10 \mathrm{nM})$ but that was unaffected by pirenzepine $(1 \mu \mathrm{M})$, AFDX116 $(5 \mu \mathrm{M})$ and PD102807 $(10 \mu \mathrm{M})$, the M1, M2 and M4 muscarinic-receptor antagonists respectively 




Fig. 7.

Cholinergic $\mathrm{Ca}^{2+}$ transients in guinea-pig smooth muscle cells. a Effect of neostigmine and 4-DAMP on spontaneous $\mathrm{Ca}^{2+}$ transients. Histogram showing the number of spontaneous $\mathrm{Ca}^{2+}$ transients recorded in guinea-pig vas deferens smooth muscle cells, with no pulse, 1 pulse and 50 pulses at $10 \mathrm{~Hz}$, in control, in the presence of neostigmine $(10 \mu \mathrm{M})$ and blocked by 4-DAMP (10 nM). b Spontaneous $\mathrm{Ca}^{2+}$ transients. 1 Control. 2 In the presence of neostigmine (shown by green arrows). 3 Blocked by 4-DAMP. c Evoked $\mathrm{Ca}^{2+}$ transients in the presence of prazosin and a, $\beta$-MeATP by trains of 50 pulses at $10 \mathrm{~Hz} ; \mathrm{Ca}^{2+}$ wave travelling along vas deferens preparation 